NASA/TM-2003-212701

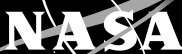

\title{
Alumina-Reinforced Zirconia Composites
}

\author{
Sung R. Choi
}

Ohio Aerospace Institute, Brook Park, Ohio

Narottam P. Bansal

Glenn Research Center, Cleveland, Ohio 
Since its founding, NASA has been dedicated to the advancement of aeronautics and space science. The NASA Scientific and Technical Information (STI) Program Office plays a key part in helping NASA maintain this important role.

The NASA STI Program Office is operated by Langley Research Center, the Lead Center for NASA's scientific and technical information. The NASA STI Program Office provides access to the NASA STI Database, the largest collection of aeronautical and space science STI in the world. The Program Office is also NASA's institutional mechanism for disseminating the results of its research and development activities. These results are published by NASA in the NASA STI Report Series, which includes the following report types:

- $\quad$ TECHNICAL PUBLICATION. Reports of completed research or a major significant phase of research that present the results of NASA programs and include extensive data or theoretical analysis. Includes compilations of significant scientific and technical data and information deemed to be of continuing reference value. NASA's counterpart of peerreviewed formal professional papers but has less stringent limitations on manuscript length and extent of graphic presentations.

- TECHNICAL MEMORANDUM. Scientific and technical findings that are preliminary or of specialized interest, e.g., quick release reports, working papers, and bibliographies that contain minimal annotation. Does not contain extensive analysis.

- CONTRACTOR REPORT. Scientific and technical findings by NASA-sponsored contractors and grantees.
- CONFERENCE PUBLICATION. Collected papers from scientific and technical conferences, symposia, seminars, or other meetings sponsored or cosponsored by NASA.

- SPECIAL PUBLICATION. Scientific, technical, or historical information from NASA programs, projects, and missions, often concerned with subjects having substantial public interest.

- TECHNICAL TRANSLATION. Englishlanguage translations of foreign scientific and technical material pertinent to NASA's mission.

Specialized services that complement the STI Program Office's diverse offerings include creating custom thesauri, building customized databases, organizing and publishing research results ... even providing videos.

For more information about the NASA STI Program Office, see the following:

- Access the NASA STI Program Home Page at http://www.sti.nasa.gov

- E-mail your question via the Internet to help@sti.nasa.gov

- Fax your question to the NASA Access Help Desk at 301-621-0134

- Telephone the NASA Access Help Desk at 301-621-0390

- Write to:

NASA Access Help Desk

NASA Center for AeroSpace Information 7121 Standard Drive

Hanover, MD 21076 
NASA/TM-2003-212701

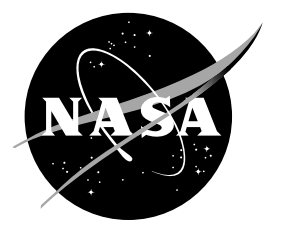

\section{Alumina-Reinforced Zirconia Composites}

Sung R. Choi

Ohio Aerospace Institute, Brook Park, Ohio

Narottam P. Bansal

Glenn Research Center, Cleveland, Ohio

National Aeronautics and

Space Administration

Glenn Research Center 


\section{Acknowledgments}

The authors are grateful to Ralph Pawlik for mechanical testing, John Setlock for materials processing, and Ralph Garlick for x-ray diffraction analysis. This work was funded by Zero $\mathrm{CO}_{2}$ Emission Technology (ZCET) Project of the Aerospace Propulsion and Power Program, NASA Glenn Research Center, Cleveland, Ohio.

This report is a formal draft or working

paper, intended to solicit comments and ideas from a technical peer group.
Trade names or manufacturers' names are used in this report for identification only. This usage does not constitute an official endorsement, either expressed or implied, by the National Aeronautics and Space Administration.

This work was sponsored by the Low Emissions Alternative

Power Project of the Vehicle Systems Program at the NASA Glenn Research Center.

Available from

NASA Center for Aerospace Information 7121 Standard Drive

Hanover, MD 21076
National Technical Information Service 5285 Port Royal Road Springfield, VA 22100 


\title{
ALUMINA-REINFORCED ZIRCONIA COMPOSITES
}

\author{
Sung R. Choi, ${ }^{*}$ and Narottam P. Bansal \\ National Aeronautics and Space Administration \\ Glenn Research Center \\ Cleveland, Ohio 44135 \\ Phone: 216-433-8366, E-mail: Sung.R.Choi@grc.nasa.gov \\ Phone: 216-433-3855, E-mail: Narottam.P.Bansal@grc.nasa.gov
}

\begin{abstract}
Alumina-reinforced zirconia composites, used as electrolyte materials for solid oxide fuel cells, were fabricated by hot pressing $10 \mathrm{~mol} \%$ yttria-stabilized zirconia (10-YSZ) reinforced with two different forms of alumina-particulates and platelets_each containing 0 to $30 \mathrm{~mol} \%$ alumina. Major mechanical and physical properties of both particulate and platelet composites including flexure strength, fracture toughness, slow crack growth, elastic modulus, density, Vickers microhardness, thermal conductivity, and microstructures were determined as a function of alumina content either at $25{ }^{\circ} \mathrm{C}$ or at both 25 and $1000{ }^{\circ} \mathrm{C}$. Flexure strength and fracture toughness at $1000{ }^{\circ} \mathrm{C}$ were maximized with $30 \mathrm{~mol} \%$ particulate and $30 \mathrm{~mol} \%$ platelet composites, respectively, while resistance to slow crack growth at $1000{ }^{\circ} \mathrm{C}$ in air was greater for $30 \mathrm{~mol} \%$ platelet composite than for $30 \mathrm{~mol} \%$ particulate composites.
\end{abstract}

\section{Introduction}

Solid oxide fuel cells (SOFC) are currently being developed for various applications in the automobile, power generation, aeronautic, and other industries. More recently, NASA has explored the possibility of using SOFCs for aeropropulsion under its Zero Carbon Dioxide Emission Technology (ZCET) Project in the Aerospace Propulsion and Power Program. The SOFC has high-energy conservation efficiency since it converts chemical energy directly into electrical energy. The SOFC is an all solid-state energy conversion device that produces electricity by electrochemical combination of a fuel cell with an oxidant at elevated temperature. The major components of an SOFC are the electrolyte, the anode, the cathode, and the interconnect. The two porous electrodes, anode and cathode, are separated by a fully dense solid electrolyte. Currently, yttria-stabilized zirconia (YSZ) is the most commonly used electrolyte in SOFC because of its high oxygen ion conductivity, stability in both oxidizing and reducing environments, availability, and low cost [1].

In solid oxide fuel cells, YSZ is used in the form of polycrystalline thin films or layers. YSZ must be fabricated in the form of fully dense layers for use as a solid electrolyte in SOFC. Similar to other ceramics, YSZ is brittle and susceptible to fracture due to the existence of flaws, which are introduced during fabrication and use of the SOFC. In addition, the properties of YSZ such as low thermal conductivity and relatively high thermal-expansion coefficient make this material thermal-shock sensitive. Fracture in the solid oxide electrolyte will allow the fuel and oxidant to come in contact with each other resulting in reduced cell efficiency or in some cases malfunction of the SOFC. Therefore, from a structural reliability/life point of view, YSZ solid electrolyte requires high fracture toughness, high strength, and enhanced resistance to slow crack growth at operating temperature (around $1000{ }^{\circ} \mathrm{C}$ ).

To improve the strength and fracture toughness of YSZ, $10 \mathrm{~mol} \%$ yttria-stabilized zirconia (10-YSZ) was reinforced with two different forms of alumina particulates and platelets, each containing $0,5,10,20$, and $30 \mathrm{~mol} \%$ alumina through mixing, milling, and hot pressing to full density. This

\footnotetext{
* NASA Senior Resident Research Scientist, Ohio Aerospace Institute, Cleveland, Ohio.
} 
chapter presents flexure strength and fracture toughness of both particulate and platelet composites, determined at both 25 and $1000{ }^{\circ} \mathrm{C}$ in air as a function of alumina content, together with elastic modulus, density, microhardness, thermal conductivity, and other properties. Slow crack growth required for component design and life prediction is also presented, evaluated in flexure at $1000{ }^{\circ} \mathrm{C}$ in air using dynamic fatigue testing for selected materials including 0 mol\% (10-YSZ matrix), 30 mol\% particulate and platelet composites.

\section{Composites Processing}

The starting materials used were 10 mol\% yttria fully stabilized zirconia powder (HSY-10, average particle size $0.41 \mu \mathrm{m}$, specific surface area $5.0 \mathrm{~m}^{2} / \mathrm{g}$ ) from Daiichi Kigenso Kagaku Kogyo Co., Japan, alumina powder [2,3] (high purity BAILALOX CR-30, 99.99\% purity, average particle size $0.05 \mu \mathrm{m}$, specific area $25 \mathrm{~m}^{2} / \mathrm{g}$ ) from Baikowski International Corporation, Charlotte, NC, and alpha alumina hexagonal platelets (Pyrofine Plat Grade T2) [4-6] from Elf Atochem, France. Appropriate quantities of alumina and zirconia powders were slurry mixed in acetone and mixed for $\sim 24 \mathrm{~h}$ using zirconia media. Acetone was than evaporated and the powder dried in an electric oven. The resulting powder was loaded into a graphite die and hot pressed at $1500{ }^{\circ} \mathrm{C}$ in vacuum under $30 \mathrm{MPa}$ pressure into $152 \mathrm{~mm} \times$ $152 \mathrm{~mm}$ billets using a hot press. Grafoil was used as spacers between the specimen and the punches. Various hot pressing cycles were tried in order to optimize the hot pressing parameters that would result in dense and crack-free ceramic samples. Five different YSZ/alumina composites containing 0 to $30 \mathrm{~mol} \%$ alumina were fabricated for each

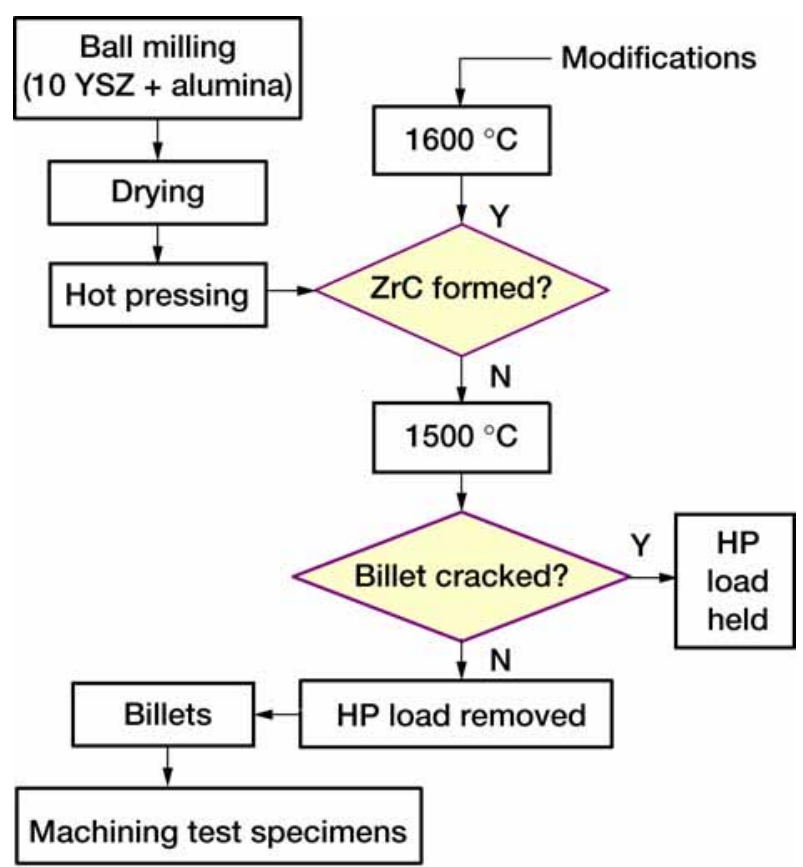

Figure 1. Processing flow diagram for 10 mol\% yttria-stabilized zirconia/alumina composites [3]. particulate and platelet composite systems. The various steps involved during processing of the composite billets are illustrated in Figure 1 [3].

\section{Test Specimen Preparation}

The billets were machined into flexure test specimens with nominal depth, width, and length of $3.0 \mathrm{~mm} \times 4.0 \mathrm{~mm} \times 50 \mathrm{~mm}$, respectively, in accordance with ASTM test standard C 1161 [7]. Machining direction was longitudinal along the 50-mm-length direction. It should be noted that unlike transformation-toughened (from tetragonal to monoclinic) zirconias, the cubic ytrria-stabilized zirconia is very unlikely to induce transformation-associated residual stresses on the surfaces of test specimens due to machining. The sharp edges of test specimens were chamfered to reduce any spurious premature failure emanating from those sharp edges. 


\section{Microstructural Analysis and Density}

$\mathrm{X}$-ray diffraction (XRD) patterns were recorded at room temperature using a step scan procedure $\left(0.02^{\circ} / 2 \theta\right.$ step, time per step 0.5 or $\left.1 \mathrm{~s}\right)$ on a Philips ADP-3600 automated diffractometer equipped with a crystal monochromator employing $\mathrm{Cu} \mathrm{K}_{\alpha}$ radiation [3]. Microstructural analysis was carried out using SEM and TEM, and limited fractographic analysis was performed optically to examine fracture origins and their nature. Typical micrographs by SEM for polished cross-sections-planes normal to hot pressing direction - of 20 mol\% particulate and platelet composites are shown in Figure 2. The dark areas represent alumina particulates or platelets while the light areas indicate the 10-YSZ matrix, as analyzed through SEM/EDS [2,3]. The alumina phases were uniformly dispersed within the major continuous 10-YSZ phase. Typical results of XRD analysis, showing phases of cubic YSZ and $\alpha$-alumina, are presented in Figure 3. An almost identical XRD result was also observed for the platelet composites. TEM micrographs and dot maps for the particulate composites indicated that an average equiaxed grain size was about less than $1.0 \mu \mathrm{m}$ for either YSZ matrix or alumina and that grain boundaries and triple junctions were clean, an indication of no existence of amorphous phase [3]. No appreciable deformation or microcracks of adjacent grains that might occur due to thermoelastic mismatches between YSZ matrix and alumina particulates were observed in the composites [3].
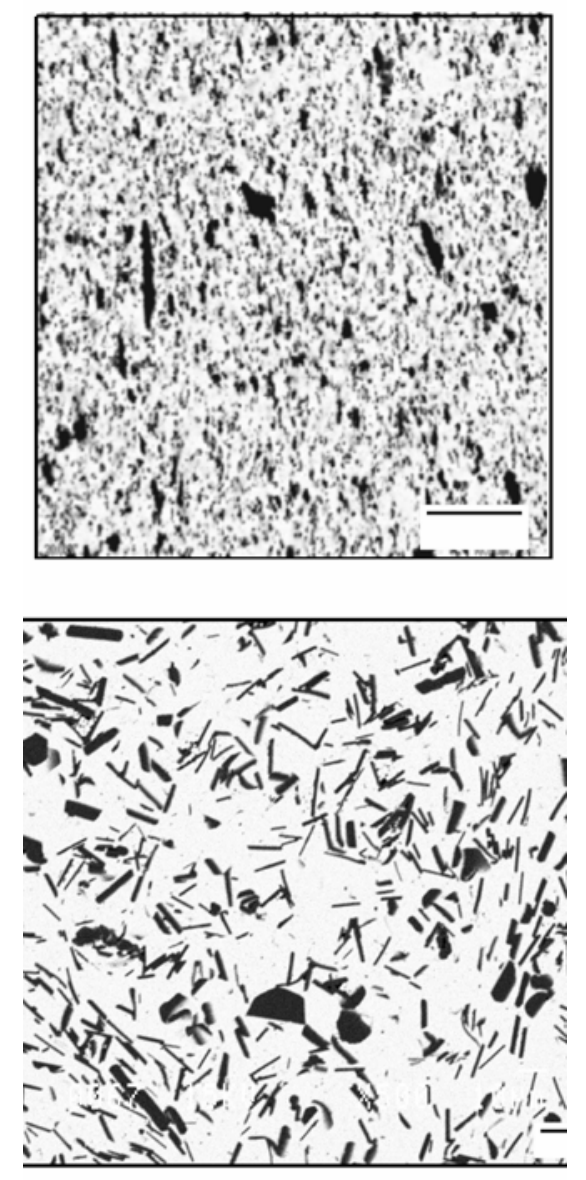

Figure 2. SEM micrographs showing polished cross-sections of $10-\mathrm{YSZ} / 20 \mathrm{~mol} \%$ alumina particulate and platelet composites: (a) particulate [3]; (b) platelet. Bars $=10 \mu \mathrm{m}$.

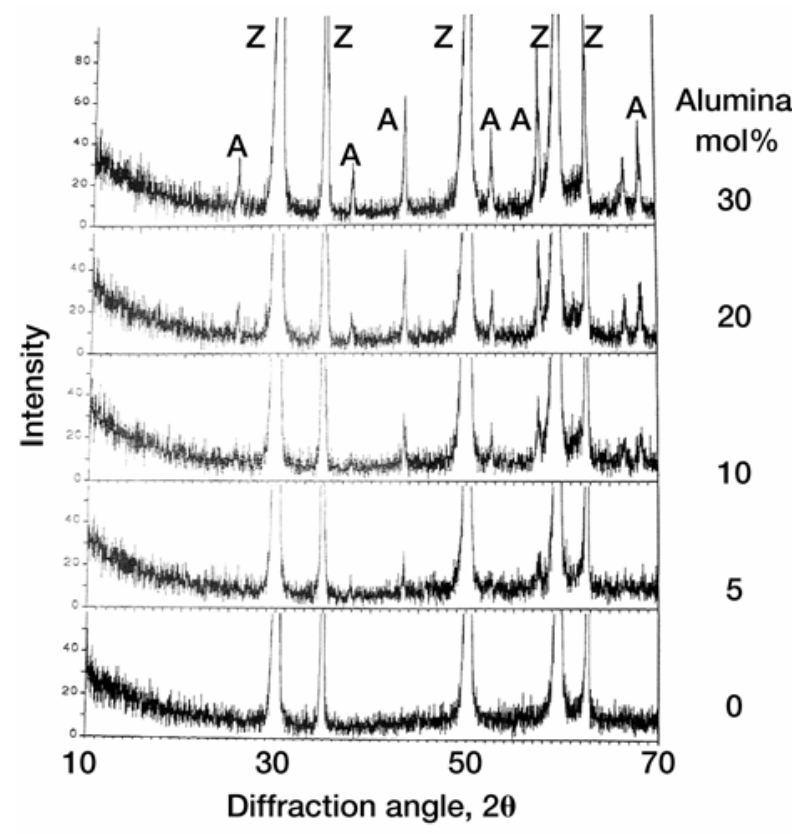

Figure 3. X-ray diffraction patterns for 10 -YSZ/alumina particulate composites. "Z" and "A" indicate cubic YSZ and $\alpha$-alumina, respectively [3]. 


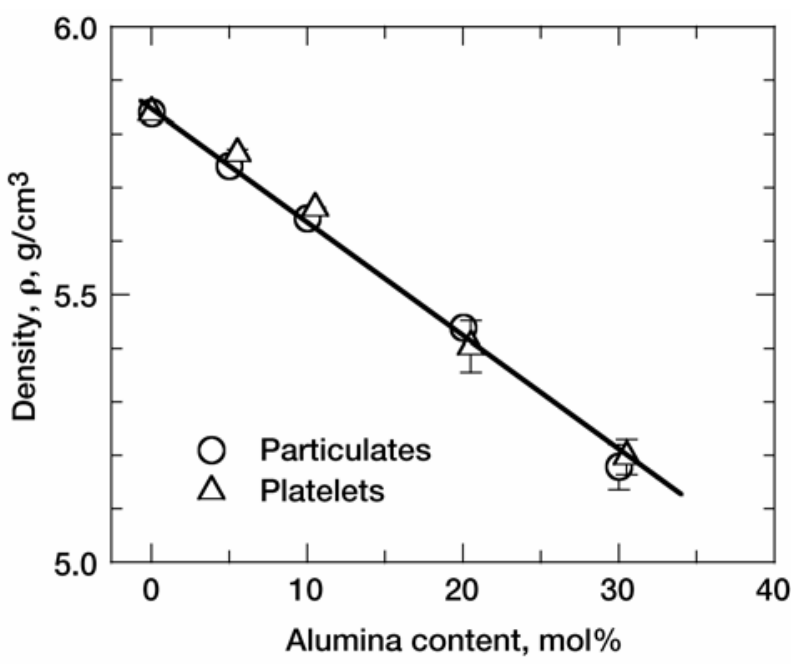

Figure 4. Density as a function of alumina content for both 10-YSZ/alumina particulate and platelet composites. Error bars indicate \pm 1.0 standard. The line indicates the prediction based on the rule of mixture $[3,4]$.

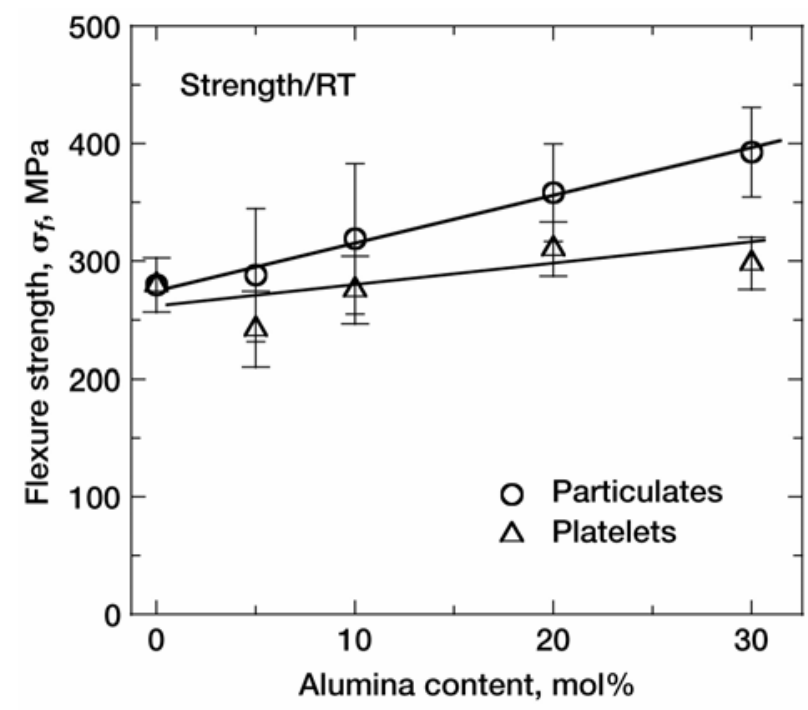

Figure 5. Flexure strength of as a function of alumina content for both 10-YSZ/alumina particulate and platelet composites at ambient temperature in air [2,4]. Error bars indicate \pm 1.0 standard deviations.

Density was measured with a bulk mass/volume method using the same flexure specimens that were used in elastic modulus measurements. A total of five specimens were used for each of alumina contents. Figure 4 depicts density as a function of alumina content for both particulate and platelet composites [3,4]. Density decreased linearly with increasing alumina content for both composite systems, yielding good agreement with the prediction based on the rule of mixture. The difference in density between particulate and platelet composites was negligible.

\section{Mechanical Properties}

\subsection{Flexure Strength}

Flexure strength was determined as a function of alumina content for both particulate and platelet composites at 25 and $1000{ }^{\circ} \mathrm{C}$ in air. A SiC four-point flexure fixture with 20 -mm-inner and 40 -mmouter spans was used in conjunction with an electromechanical test frame (Model 8562, Instron, Canton, MA). A fast test rate of $50 \mathrm{MPa} / \mathrm{s}$ was applied in load control to minimize slow crack growth effect of the materials. ${ }^{\dagger}$ For a given temperature, a total of 10 test specimens were tested for each of alumina contents. Testing was followed in accordance with ASTM test standards C1161 and C 1211 [9].

The results of strength testing at $25^{\circ} \mathrm{C}$ are shown in Figure 5. Strength of the particulate composites increased with increasing alumina content, reaching a maximum at $30 \mathrm{~mol} \%$, while strength of the platelet composites remained almost unchanged with increasing alumina content, except at $5 \mathrm{~mol} \%$. Hence, increase in strength was much more significant in the particulate composites than in the platelet composites. For a given alumina content, strength of the particulate composites was 15 to 30 percent

\footnotetext{
${ }^{\dagger}$ Elevated-temperature strength of many advanced ceramics depends on test rate due to slow crack growth during testing. It has shown that elevated-temperature strength of advanced ceramics increases with increasing test rate and converges to ambient-temperature strength (or inert strength) at "ultra"-fast test rates $\geq 10^{5} \mathrm{MPa} / \mathrm{s}$ [8]. Although the test rate of $50 \mathrm{MPa} / \mathrm{s}$ used in this work was not sufficient to obtain an appropriate "inert" strength whereby no slow crack growth occurs, the test rate of $50 \mathrm{MPa} / \mathrm{s}$ was chosen to determine the conventional, so-called "fast-fracture" strength of the material in which a test rate of around 30 to $100 \mathrm{MPa} / \mathrm{s}$ is typically employed.
} 
greater than the platelet composite counterpart. Particularly, the maximum strength occurring at $30 \mathrm{~mol} \%$ for the particulate composite was 40 percent greater than the 10-YSZ (matrix) strength. Fracture originated from surface defects, associated with pores and machining damage in many cases. Typical examples of fracture surfaces of specimens showing surface-flaw-associated failure are shown in Figure 6.

The results of elevated-temperature strength testing for both particulate and platelet composites are presented in Figure 7 as a function of alumina content. Like the ambient-temperature counterpart, elevated-temperature strength of the platelet composites did not exhibit any significant dependency on alumina content. The maximum strength occurring at $10 \mathrm{~mol} \%$ was about 17 percent greater than the 10 -YSZ strength. Strength of the platelet composites was greater at 5 and 10 mol\% but lower at 20 and $30 \mathrm{~mol} \%$ than the particulate composite counterpart. Strength of the particulate composites with respect to the 10 -YSZ strength decreased initially at $5 \mathrm{~mol} \%$ and increased thereafter with increasing alumina content, reaching a maximum at $30 \mathrm{~mol} \%$. The maximum strength of the particulate composites at $30 \mathrm{~mol} \%$ was 40 percent greater than the 10 -YSZ strength. Also, the particulate composite strength at

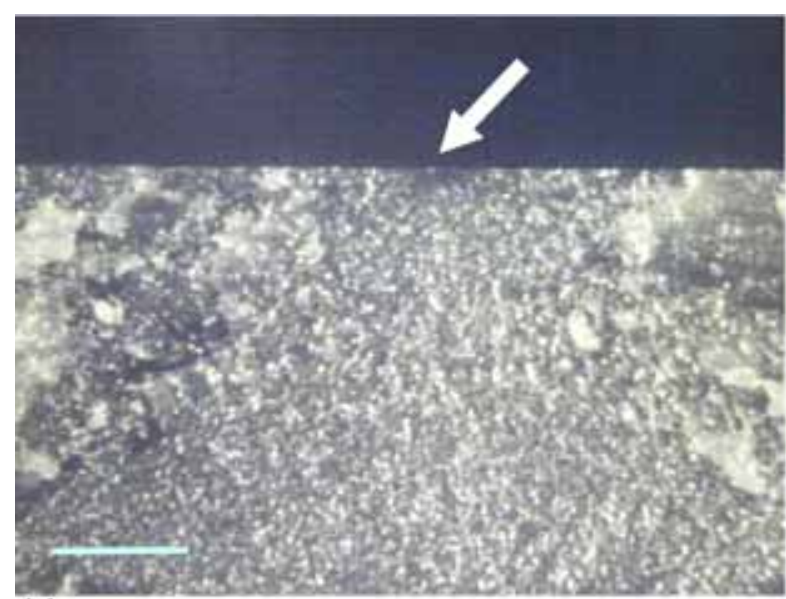

(a)

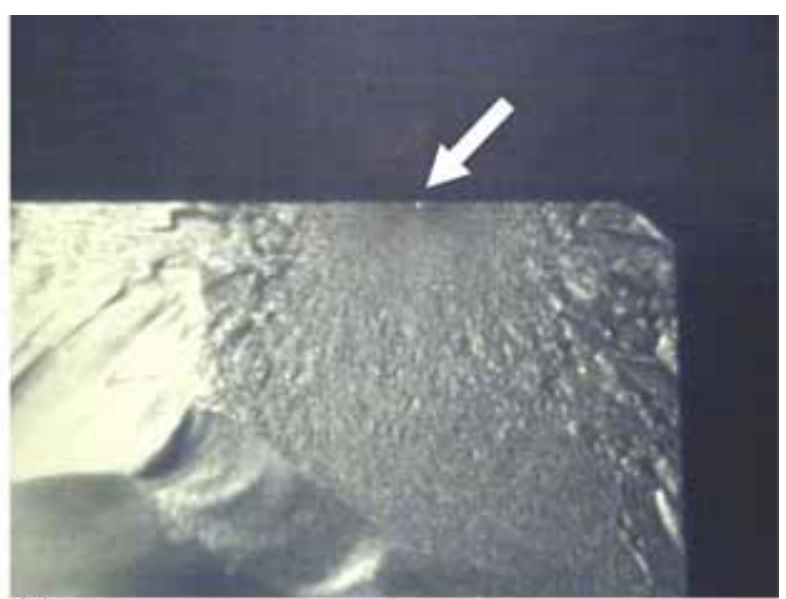

(b)

Figure 6. Typical examples of fracture surfaces showing fracture origins for (a) 0 mol\% (10-YSZ); (b) $30 \mathrm{~mol} \%$ alumina particulate composite [2]. Bar $=500 \mu \mathrm{m}$.

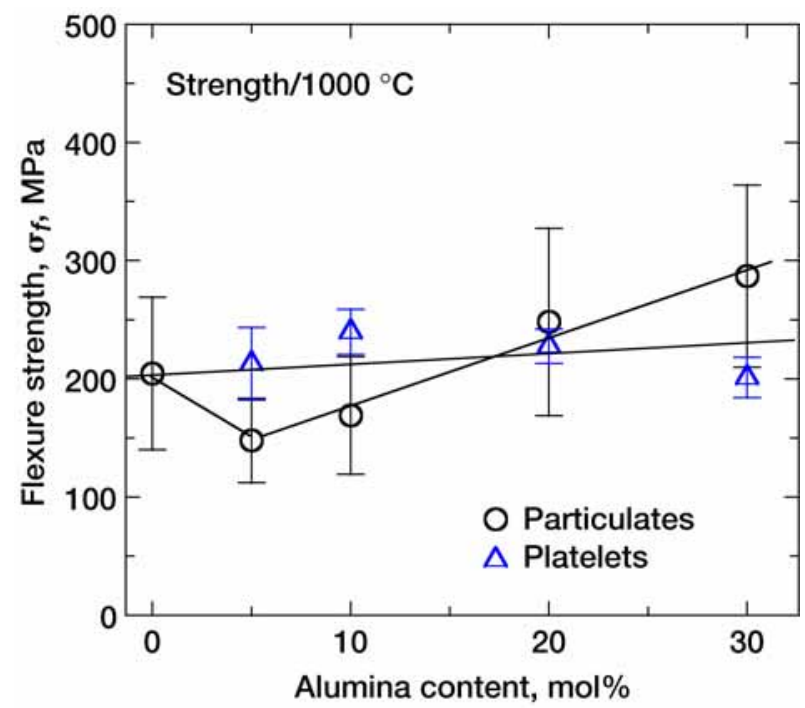

Figure 7. Flexure strength as a function of alumina content for both 10-YSZ/alumina particulate and platelet composites at $1000^{\circ} \mathrm{C}$ in air [2,5,6]. Error bars indicate \pm 1.0 standard deviations. 
30 mol\% was 30 percent greater than the respective platelet composite strength. The overall elevatedtemperature strength of the two composite systems for a given alumina content was lower (20 to 50 percent and 10 to 30 percent, respectively, for the particulate and platelet composites) than their ambient-temperature counterpart, attributed to strength degradation at elevated temperature presumably by slow crack growth phenomenon. Individual strength data of both composites at 25 and $1000{ }^{\circ} \mathrm{C}$ are summarized in Tables 1 and 2.

Table 1. Summary of major mechanical and physical properties of 10-YSZ reinforced with alumina particulates [2-6, 30]

\begin{tabular}{|c|c|c|c|c|c|c|}
\hline \multicolumn{2}{|c|}{$\mathrm{P}_{\text {Properties }}^{\text {Alumina mol\% }}$} & 0 & 5 & 10 & 20 & 30 \\
\hline \multirow{2}{*}{$\begin{array}{l}\text { Flexure } \\
\text { strength, } \sigma_{f} \\
\text { (MPa) }\end{array}$} & RT & $279.6(23.1)^{a}$ & $287.9(56.7)$ & $318.8(64.1)$ & $358.1(41.5)$ & 353.6(89.1) \\
\hline & $1000^{\circ} \mathrm{C}$ & $204.5(64.5)$ & $147.8(35.7)$ & $169.0(49.7)$ & $248.1(79.3)$ & $287.0(77.0)$ \\
\hline \multirow{2}{*}{$\begin{array}{l}\text { Fracture } \\
\text { toughness, } \\
\mathrm{K}_{\mathrm{IC}} \\
(\mathrm{MPa} \sqrt{\mathrm{m}}) \\
\end{array}$} & RT & $1.6(0.1)$ & $2.1(0.3)$ & $1.7(0.2)$ & $2.3(0.1)$ & $2.6(0.3)$ \\
\hline & $1000{ }^{\circ} \mathrm{C}$ & $1.7(0.2)$ & $2.3(0.2)$ & $1.5(0.2)$ & $2.3(0.2)$ & $2.6(0.3)$ \\
\hline \multicolumn{2}{|c|}{$\begin{array}{l}\text { RT elastic modulus, } \\
\text { E (GPa) }\end{array}$} & $219(2)$ & $225(2)$ & $233(1)$ & $250(1)$ & $262(2)$ \\
\hline \multicolumn{2}{|c|}{ Density, $\rho\left(\mathrm{g} / \mathrm{cm}^{3}\right)$} & $5.839(0.008)$ & $5.740(0.012)$ & $5.642(0.007)$ & $5.437(0.005)$ & $5.178(0.042)$ \\
\hline \multicolumn{2}{|c|}{$\begin{array}{l}\text { RT Vickers hardness, } \\
\text { H (GPa) }\end{array}$} & $14.1(0.6)$ & $14.5(0.2)$ & $14.9(0.1)$ & $15.7(0.3)$ & $15.4(0.4)$ \\
\hline \multicolumn{2}{|c|}{$\begin{array}{l}\text { Thermal conductivity at } \\
1000^{\circ} \mathrm{C}, \mathrm{k}(\mathrm{W} / \mathrm{m}-\mathrm{K})\end{array}$} & 2.2 & 2.5 & 2.7 & 3.0 & 3.3 \\
\hline
\end{tabular}

${ }^{a}$ The numbers in parentheses indicate \pm 1.0 standard deviation.

Table 2. Summary of major mechanical and physical properties of 10-YSZ reinforced with alumina platelets [2-6]

\begin{tabular}{|c|c|c|c|c|c|c|}
\hline \multicolumn{2}{|c|}{$\begin{array}{c}\text { Alumina mol\% } \\
\text { Properties } \\
\end{array}$} & 0 & 5 & 10 & 20 & 30 \\
\hline \multirow{2}{*}{$\begin{array}{l}\text { Flexure } \\
\text { strength, } \sigma_{f} \\
(\mathrm{MPa})\end{array}$} & RT & $279.6(23.1)^{a}$ & 241.9(32.3) & $275.4(28.9)$ & $310.1(22.9)$ & $297.9(22.2)$ \\
\hline & $1000^{\circ} \mathrm{C}$ & $204.5(64.5)$ & 212.8(30.6) & $239.7(19.0)$ & $227.6(14.5)$ & 201.1(17.1) \\
\hline \multirow{2}{*}{$\begin{array}{l}\text { Fracture } \\
\text { toughness, } \\
\mathrm{K}_{\mathrm{IC}} \\
(\mathrm{MPa} \sqrt{\mathrm{m}})\end{array}$} & RT & $1.6(0.1)$ & $1.7(0.1)$ & $1.8(0.1)$ & $2.2(0.1)$ & $2.6(0.1)$ \\
\hline & $1000^{\circ} \mathrm{C}$ & $1.7(0.2)$ & $2.6(0.5)$ & $2.7(0.4)$ & $2.9(0.1)$ & $3.0(0.1)$ \\
\hline \multicolumn{2}{|c|}{$\begin{array}{l}\text { RT elastic modulus, } \mathrm{E} \\
(\mathrm{GPa})\end{array}$} & $219(2)$ & $226(2)$ & $234(1)$ & $245(1)$ & $259(2)$ \\
\hline \multicolumn{2}{|c|}{ Density, $\rho\left(\mathrm{g} / \mathrm{cm}^{3}\right)$} & $5.839(0.008)$ & $5.764(0.008)$ & $5.661(0.002)$ & $5.403(0.048)$ & $5.197(0.033)$ \\
\hline \multicolumn{2}{|c|}{$\begin{array}{l}\text { Vickers hardness, } \\
\mathrm{H}(\mathrm{GPa})\end{array}$} & $14.1(0.6)$ & $14.2(0.6)$ & $14.2(0.7)$ & $13.6(0.6)$ & $11.5(0.6)$ \\
\hline
\end{tabular}

${ }^{\mathrm{a}}$ The numbers in parentheses indicate \pm 1.0 standard deviation. 
The strength scatter at $1000{ }^{\circ} \mathrm{C}$ was less significant in the platelet composites than in the particulate composites. Weibull modulus $(m)$, estimated despite a limited number $(10)$ of specimens tested at each alumina content, was in the range of $m=8$ to 20 and $m=5$ to 10, respectively, for the platelet and the particulate composites. Fracture originated mainly from surface flaws for both composites. However, platelets, particularly at $1000{ }^{\circ} \mathrm{C}$, were frequently associated as primary failure origins, so that alumina platelets might have acted as strength-controlling flaws rather than as strengthening media, typical of many platelets-reinforced composites, resulting in less scatter in strength or higher Weibull modulus. The fact that the $30 \mathrm{~mol} \%$ particulate composite at both temperatures exhibited improved strength over the platelet composite is indicative of an effective approach to the reinforcement of 10-YSZ.

It has been shown that some other zirconia/alumina composites exhibited a strength decrease with increasing alumina content, in part as a result of internal (tensile) residual stresses by the CTE mismatches between zirconia matrix and alumina particulate or platelets [10,11]. Based on the results of strength increase with increasing alumina content particularly for the $30 \mathrm{~mol} \%$ particulate composite, as seen in Figure 5, it can be stated that the alumina particulates used in this work might not have interacted with the matrix to produce residual stresses by CTE mismatches sufficient enough to degrade composite strength.

\subsection{Fracture Toughness}

Fracture toughness of each of the particulate and platelet composites, using the flexure test specimens, was determined at 25 and $1000{ }^{\circ} \mathrm{C}$ in air using the single edge v-notched beam (SEVNB) method. This method utilizes a razor blade with diamond paste to introduce a final sharp root radius by tapering a saw notch [12a]. A starter straight-through notch $0.6 \mathrm{~mm}$ deep and $0.026 \mathrm{~mm}$ wide was made on the 3-mm-wide face of each test specimen. The v-notched specimens with a final notch depth of $0.9 \mathrm{~mm}$ and its root radius of about $10 \mu \mathrm{m}$ were fractured in a $\mathrm{SiC}$ four-point flexure fixture with 20 -mm-inner and 40 -mm-outer spans using the electromechanical testing machine at an actuator speed of $0.5 \mathrm{~mm} / \mathrm{min}$. A total of five specimens were tested for each composite at each test temperature. A typical example of v-notched fracture toughness test specimen is shown in Figure 8. It should be mentioned that an attempt was made to utilize a more convenient fracture toughness technique, single edge precracked

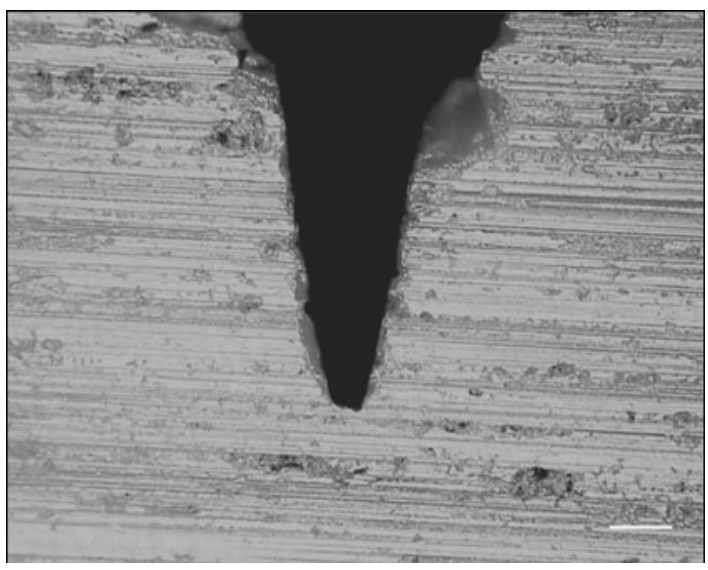

Figure 8. A typical example of a sharp v-notch produced in a single edge V-notched beam (SEVNB) specimen used in fracture toughness testing [2]. Bar $=50 \mu \mathrm{m}$. beam (SEPB) method (ASTM C 1421 [13]) at both RT and $1000{ }^{\circ} \mathrm{C}$. However, this technique was found to be ineffective at $1000{ }^{\circ} \mathrm{C}$ due to crack healing by oxidation, which resulted in a considerably high "apparent" value of fracture toughness, as observed in other ceramics such as silicon nitride and alumina [14]. The SEVNB method, however, may underestimate fracture toughness at ambient temperature (compared to other methods such as SEPB and/or chevron notch) if a material exhibits strong R-curve behavior, since the method tends to give a starting value of fracture toughness on the corresponding R-curve [12(b)]. The fracture toughness $K_{\text {IC }}$ was calculated based on the formula by Srawley and Gross [15].

$$
K_{\mathrm{IC}}=\frac{P_{f}\left(L_{o}-L_{i}\right)}{B W^{3 / 2}} \frac{3 \alpha^{1 / 2}}{2(1-\alpha)^{3 / 2}} f(\alpha)
$$


where $P_{f}, L_{o}, L_{i}, B, W$ are fracture load, outer span, inner span, specimen width, and specimen depth, respectively, $\alpha=a / \mathrm{W}$ with $a$ being precrack size, and $f(\alpha)$ is expressed

$$
f(\alpha)=1.9887-1.326 \alpha-\frac{\alpha(1-\alpha)\left(3.49-0.68 \alpha+1.35 \alpha^{2}\right)}{(1+\alpha)^{2}}
$$

A summary of the results of fracture toughness testing at $25^{\circ} \mathrm{C}$ in air is presented in Figure 9 , in which fracture toughness determined by the SEVNB method was plotted as a function of alumina content for both particulate and platelet composites. Similar to the trend in ambient-temperature flexure strength, fracture toughness increased with increasing alumina content, reaching a maximum at $30 \mathrm{~mol} \%$. Fracture toughness increased significantly by 65 and 62 percent, respectively, for the particulate and platelet composites when alumina content increased from 0 to $30 \mathrm{~mol} \%$. It is noted that unlike the ambient-temperature flexure strength the difference in fracture toughness between the particulate and platelet composites was negligible. It has been observed that an incompatibility is generally operative for many advanced ceramics between strength and fracture toughness in such a manner that one property increases while the other decreases. However, this was not the case for these two types of composite systems, resulting in not only strength increase but also fracture-toughness increase with increasing alumina content.

It was observed that indent crack trajectories of both 0 percent and $30 \mathrm{~mol} \%$ particulate composites were characterized such that the straight path and greater COD (crack opening displacement) of a crack was typified for 10 -YSZ ( 0 mol\% composite); whereas, the tortuous path around alumina grains and less COD was exemplified for the $30 \mathrm{~mol} \%$ particulate or platelet composite [2]. More enhanced crack interactions with alumina grains with increasing alumina content is thus believed to be responsible for the increased fracture toughness for both composite systems. A notion that platelets would be more efficient in enhancing fracture toughness than particulates was not applicable in these composite

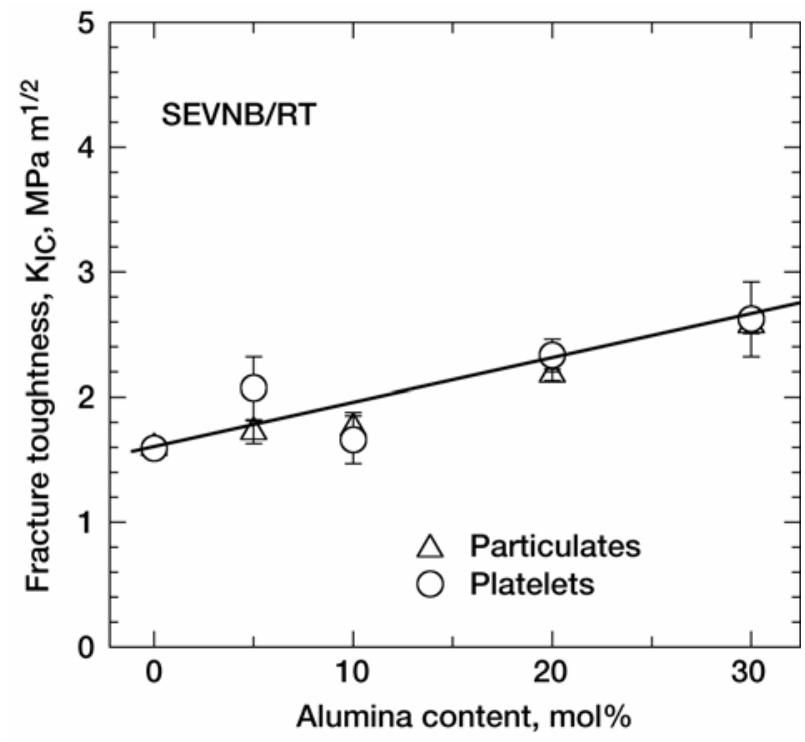

Figure 9. Fracture toughness as a function of alumina content for both 10-YSZ/alumina particulate and platelet composites, determined by the SEVNB method at room temperature $[2,4]$.

Error bars indicate \pm 1.0 standard. 

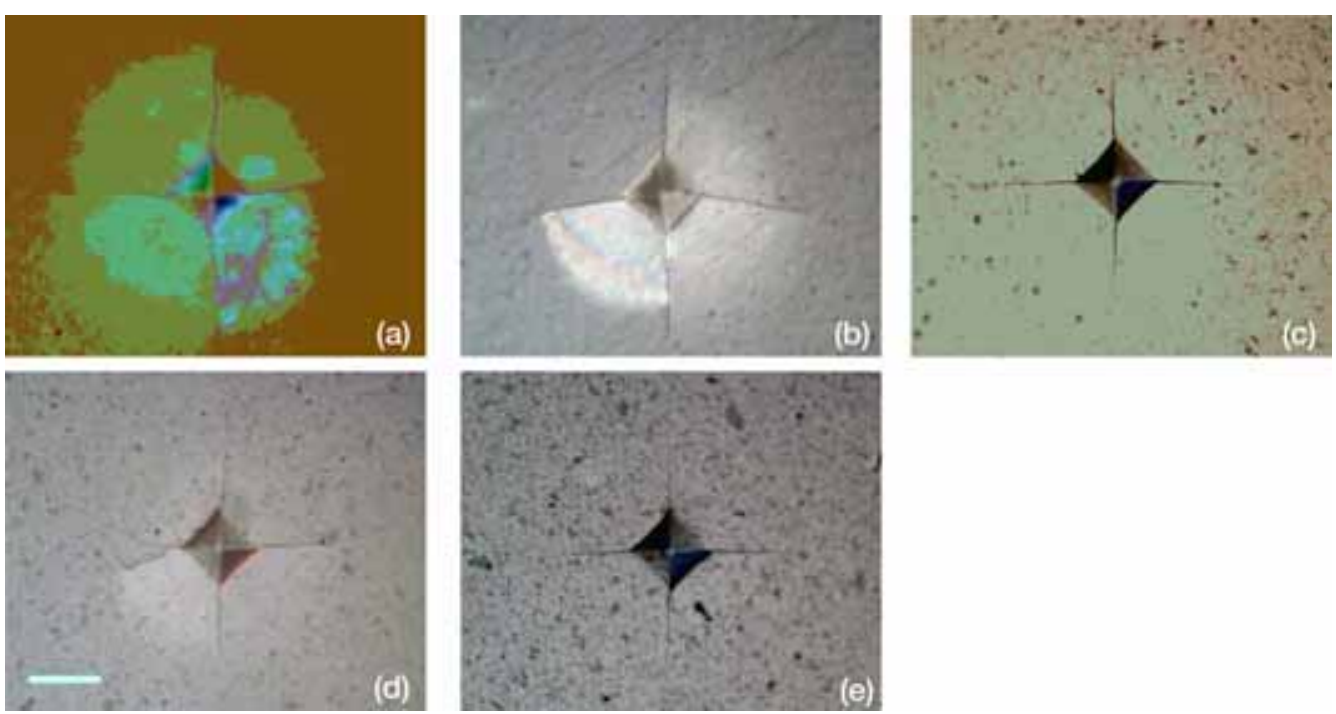

Figure 10. Response to Vickers indentation of 10-YSZ/alumina particulate composites at ambient temperature under an indent load of $10 \mathrm{~N} \mathrm{(a)} 0$ mol\%; (b) 5 mol\%; (c) $10 \mathrm{~mol} \%$; (d) $20 \mathrm{~mol} \%$;

(e) $30 \mathrm{~mol} \%$. Bar $=30 \mu \mathrm{m}$.

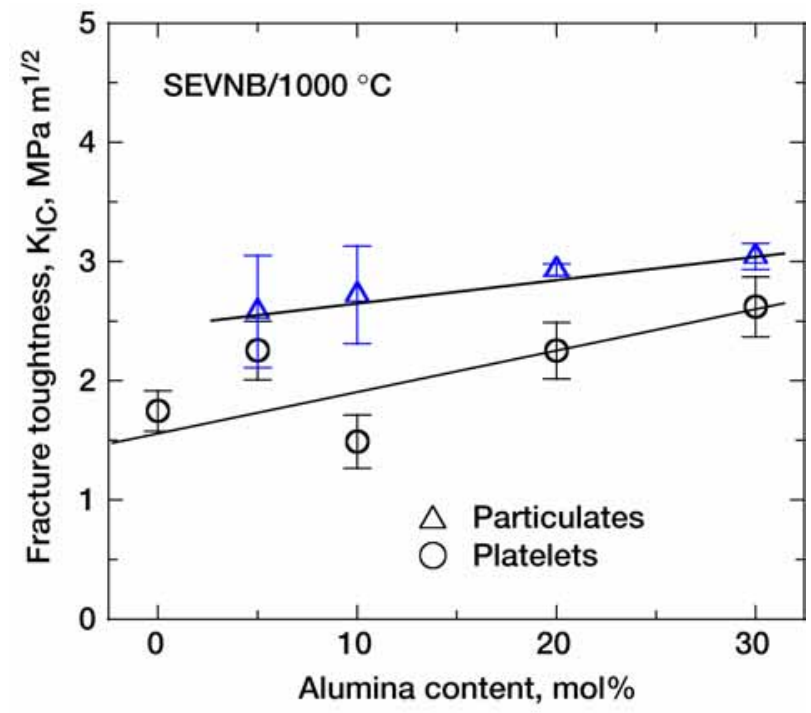

Figure 11. Fracture toughness as a function of alumina content for 10-YSZ/alumina particulate and platelet composites at $1000^{\circ} \mathrm{C}$ in air [2,5,6]. Flexure toughness of 10 -YSZ/alumina particulate composites $[2,5,6]$ is included for comparison. Error bars indicate \pm 1.0 standard deviations. The lines represent the best fit.

systems at ambient temperature. Note that the cubic YSZ is not a stress-induced, transformation toughened ceramic. Therefore, the increased fracture toughness with increasing alumina content would be a logical reasoning for the increased flexure strength observed from both composite systems, since flaw sizes of both composites seemed to be narrowly distributed. Typical responses to Vickers indentation are shown in Figure 10 for the particular composites. Note the size of indent cracks decreasing with increasing alumina content, indicative of increasing resultant fracture toughness.

A summary of fracture toughness determined at $1000{ }^{\circ} \mathrm{C}$ is presented in Figure 11 . The overall fracture toughness of both particulate and platelet composites increased with increasing alumina 


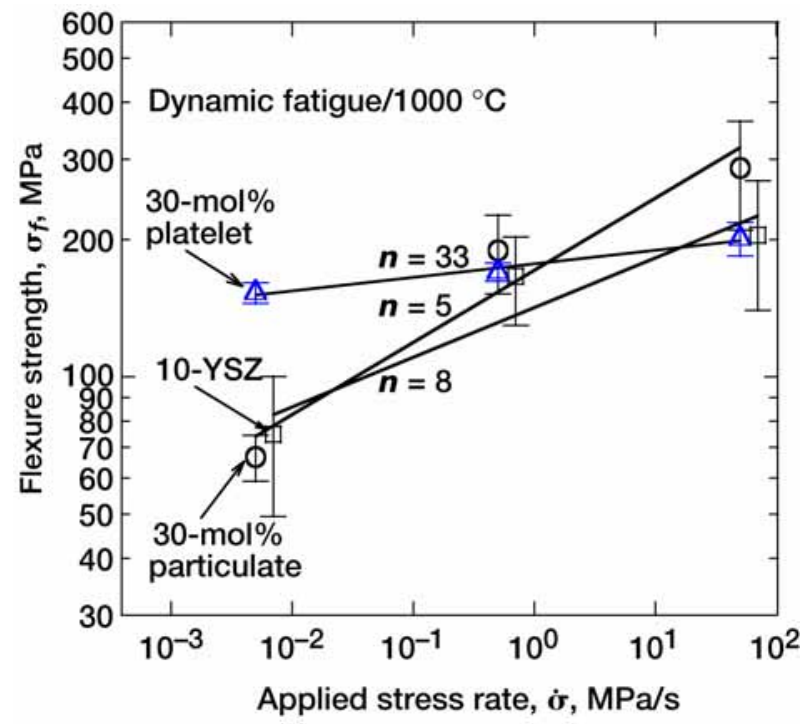

Figure 12. Results of dynamic fatigue testing at $1000{ }^{\circ} \mathrm{C}$ in air for $10-\mathrm{YSZ}, 10-\mathrm{YSZ} / 30 \mathrm{~mol} \%$ alumina particulate composite, and 10-YSZ/30 mol\% alumina platelet composite. The solid lines represent

the best-fit line. Slow crack growth parameter $n$ is included.

content, reaching a maximum at $30 \mathrm{~mol} \%$. Fracture toughness increased significantly by 50 and 74 percent, respectively, for the particulate and platelet composites when alumina content increased from 0 to $30 \mathrm{~mol} \%$. Unlike the ambient-temperature fracture toughness, the difference in fracture toughness at $1000{ }^{\circ} \mathrm{C}$, in general, was distinct between the particulate and platelet composites. This indicates that toughening by addition of platelets to 10 -YSZ matrix was more effective at $1000{ }^{\circ} \mathrm{C}$ than at $25{ }^{\circ} \mathrm{C}$. Individual fracture toughness data for both composites at 25 and $1000{ }^{\circ} \mathrm{C}$ are summarized in Tables 1 and 2.

\subsection{Slow Crack Growth (Dynamic Fatigue)}

Slow crack growth (SCG) behavior of some chosen composites was determined at $1000{ }^{\circ} \mathrm{C}$ in air using dynamic fatigue (or called constant stress rate) testing in accordance with ASTM Test Method C 1465 [16]. Three different composites including 0 mol\% (10-YSZ), $30 \mathrm{~mol} \%$ alumina particulate and $30 \mathrm{~mol} \%$ alumina platelet composites were selected based on the results of optimum strength and fracture toughness properties exhibited by $30 \mathrm{~mol} \%$ particulate and platelet composites. Dynamic fatigue testing was performed in flexure using flexure test specimens at three different test rates of 50, 0.5 , and $0.005 \mathrm{MPa} / \mathrm{s}$ for a given composite under load control of the electromechanical test frame. Note that the flexure strength data obtained at $50 \mathrm{MPa} / \mathrm{s}$ from flexure strength testing were used as one set for the dynamic fatigue data. A SiC four-point flexure fixture with 20/40 mm spans was used. Typically, a total of 7 to 10 test specimens were used at each test rate for a given composite.

The results of SCG ("dynamic fatigue" or "constant stress-rate") testing for the three different composites are shown in Figure 12, where fracture stress of each composite was plotted as a function of applied stress rate. The decrease in fracture stress with decreasing stress rate, which represents susceptibility to SCG, was evident for all three composites with its degree of strength degradation with decreasing stress rate being dependent on material. The basic underlying formulation of SCG for many advanced monolithic ceramics and composites (reinforced with particulates, platelets, or whiskers) at elevated temperatures follows the following power-law form [17]

$$
v=A\left[K_{\mathrm{I}} / K_{\mathrm{IC}}\right]^{n}
$$


where $v, K_{\mathrm{I}}$ and $K_{\mathrm{IC}}$ are crack velocity, mode I stress intensity factor, and mode I fracture toughness, respectively. $A$ and $n$ are material/environment dependent SCG parameters. The responsible mechanism of SCG at elevated temperatures has been known as grain boundary sliding [18-21]. In case of dynamic fatigue loading, a constant stress rate $(\dot{\sigma})$ is applied to a test specimen until the test specimen fails. The corresponding fracture stress $\left(\sigma_{f}\right)$ can be derived from Eq. (2) and related stress intensity factor with some mathematical manipulations to give $[16,22]$

$$
\log \sigma_{f}=\frac{1}{n+1} \log \dot{\sigma}+\log D
$$

where $D$ is another SCG parameter associated with $A, n, K_{\text {IC }}$, inert strength, and crack geometry factor. The SCG parameters $n$ and $D$ can be determined from the slope and intercept by a linear regression analysis when log (fracture stress) is plotted as a function of log (applied stress rate). Equation (3) is the basis commonly used in dynamic fatigue testing, which has been adopted to determine SCG parameters of advanced ceramics in ASTM test standards at both ambient and elevated temperatures as well $[16,23]$.

The results shown in Figure 12 were plotted according to Eq. (3) with units of MPa for $\sigma_{f}$ and $\mathrm{MPa} / \mathrm{s}$ for $\dot{\sigma}$. The SCG parameter $n$ was found to be $n=8,5$ and 33, respectively, for $0 \mathrm{~mol} \%$ (10-YSZ), $30 \mathrm{~mol} \%$ particulate and $30 \mathrm{~mol} \%$ platelet composites. The SCG parameters $n$ and $D$ are also summarized in Table 3, together with correlation coefficients of regression. Both 0 and $30 \mathrm{~mol} \%$ particulate composites exhibited very high susceptibility to SCG with a relatively low SCG parameter $n$ $=6-8$, and the $30 \mathrm{~mol} \%$ platelet composite exhibited intermediate susceptibility with $n=33 .^{\ddagger}$ Hence, the $30 \mathrm{~mol} \%$ platelet composite exhibited greater resistance to SCG as compared with both 0 and $30 \mathrm{~mol} \%$ particulate composites. The addition of $30 \mathrm{~mol} \%$ alumina platelets into 10 -YSZ matrix resulted in increased resistance to grain boundary sliding, while the addition of $30 \mathrm{~mol} \%$ fine alumina particulates would not have had any positive effect on reducing or minimizing grain boundary sliding. Note that the value of SCG parameter $n$ determined at $1000{ }^{\circ} \mathrm{C}$ in air for typical aluminas with 96 to 99 percent purity is in a range of $n=7-13$ [20,24]. Significant improvement in SCG resistance was obtained by the composite approach with 10 -YSZ reinforced with $30 \mathrm{~mol} \%$ alumina platelets, in which each of YSZ and alumina exhibits a significantly high SCG susceptibility $(n=5-13)$ if they are used individually in a form of monolith.

Table 3. Summary of slow crack growth parameters determined for three different composites by dynamic fatigue testing in flexure at $1000{ }^{\circ} \mathrm{C}$ in air

\begin{tabular}{|c|c|c|c|}
\hline \multirow{2}{*}{ Materials } & \multicolumn{2}{|c|}{$\begin{array}{c}\text { Slow crack growth } \\
\text { parameters }\end{array}$} & $\begin{array}{c}\text { Correlation } \\
\text { coefficient, } r^{2}\end{array}$ \\
\cline { 2 - 3 } & $n$ & $D$ & \\
\hline $10-$ YSZ (matrix) & 8.2 & 142 & 0.8968 \\
\hline $\begin{array}{c}10-\text { YSZ/30 mol\% } \\
\text { alumina particulate } \\
\text { composite }\end{array}$ & 5.3 & 171 & 0.9420 \\
\hline $\begin{array}{c}10-Y S Z / 30 \text { mol\% } \\
\text { alumina platelet } \\
\text { composite }\end{array}$ & 32.6 & 177 & 0.9820 \\
\hline
\end{tabular}

\footnotetext{
‡ Note that susceptibility to slow crack growth (SCG) is typically categorized in advanced ceramics such that SCG susceptibility is very high for $n<20$, intermediate for $n=30-50$, and very low for $n>50$.
} 
A simplified life prediction diagram can give a better interpretation of SCG behavior among the three composites, which was constructed in Figure 13 under the same specimen's geometrical and dimensional configurations that were used in dynamic fatigue, based on the following relation

$$
t_{f}=\left[\frac{D^{n+1}}{n+1}\right] \sigma^{-n}
$$

where $t_{\mathrm{f}}$ and $\sigma$ are time to failure (in sec) and constant applied stress (in MPa), respectively. Of course, the prediction is valid when the same failure mechanism(s) is operative, irrespective of loading condition, either dynamic or static. As can be seen from the figure, lifetime is greatest for the $30 \mathrm{~mol} \%$ platelet composite, and is least for the 10 -YSZ or the $30 \mathrm{~mol} \%$ particulate composite. As a consequence, the $30 \mathrm{~mol} \%$ platelet composite would be the most reasonable choice among the three materials in conjunction with component life. A detailed life prediction and reliability of actual, complex fuel cell components can be made using analytical (finite element modeling) and reliability tool such as CARES/Life integrated computer code [25].

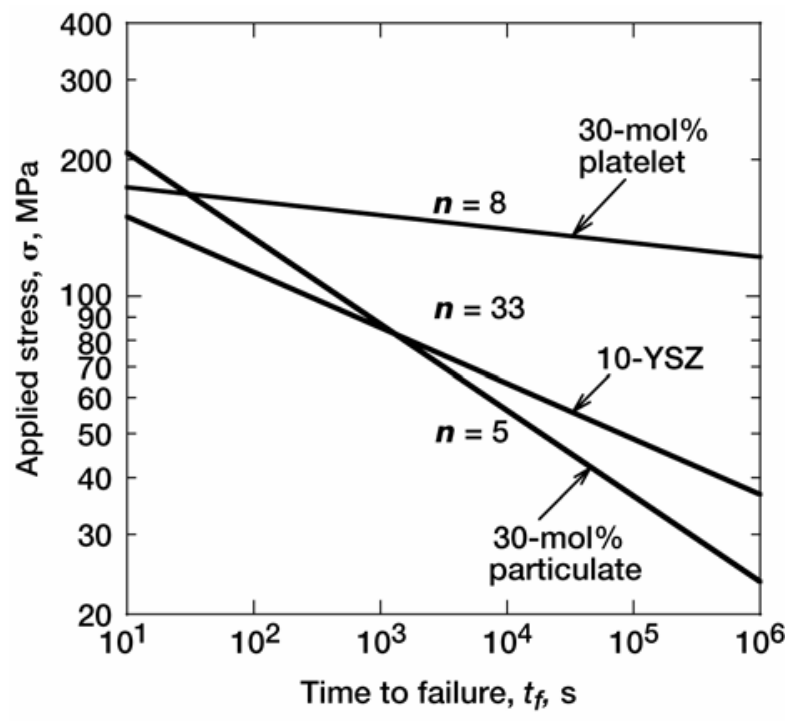

Figure 13. Life prediction diagram constructed from the dynamic fatigue results at $1000^{\circ} \mathrm{C}$ for $10-Y S Z,, 10-Y S Z / 30 \mathrm{~mol} \%$ alumina particulate composite, and 10-YSZ/30 mol\% alumina platelet composite. The prediction represents at a failure probability of 50 percent.

\subsection{Elastic Modulus}

Elastic modulus of both particulate and platelet composites was determined from 25 to $1000{ }^{\circ} \mathrm{C}$ as a function of alumina content by the impulse excitation of vibration method, ASTM C 1259 [26] using the flexure specimen configuration. One flexure specimen was used at each of alumina contents for a given composite. A total of five specimens were additionally used at each alumina content to evaluate ambient-temperature elastic modulus of the two composites.

A summary of elastic modulus as a function of temperature for the particulate composites are shown in Figure 14. Elastic modulus decreased with increasing temperature up to $400{ }^{\circ} \mathrm{C}$ and then remained almost unchanged up to $1000{ }^{\circ} \mathrm{C}$, thereby forming a unique transition around $400{ }^{\circ} \mathrm{C}$, regardless of alumina content. Although not presented here, it was also found that elastic modulus of the platelet composites was very close to that of the platelet composites. A similar transition at $400{ }^{\circ} \mathrm{C}$ was also observed in 6.5-YSZ by Adams et al. [27]. Figure 15 shows elastic modulus as a function of alumina content for both particulate and platelet composites, determined at ambient temperature. Elastic modulus increased linearly with increasing alumina content for both composites, with little difference in elastic modulus between the two composite systems for a given alumina mol\%. The prediction made based on the rule of mixture was in good agreement with the experimental data. Individual elastic modulus data at ambient temperature for both composites are summarized in Tables 1 and 2. 


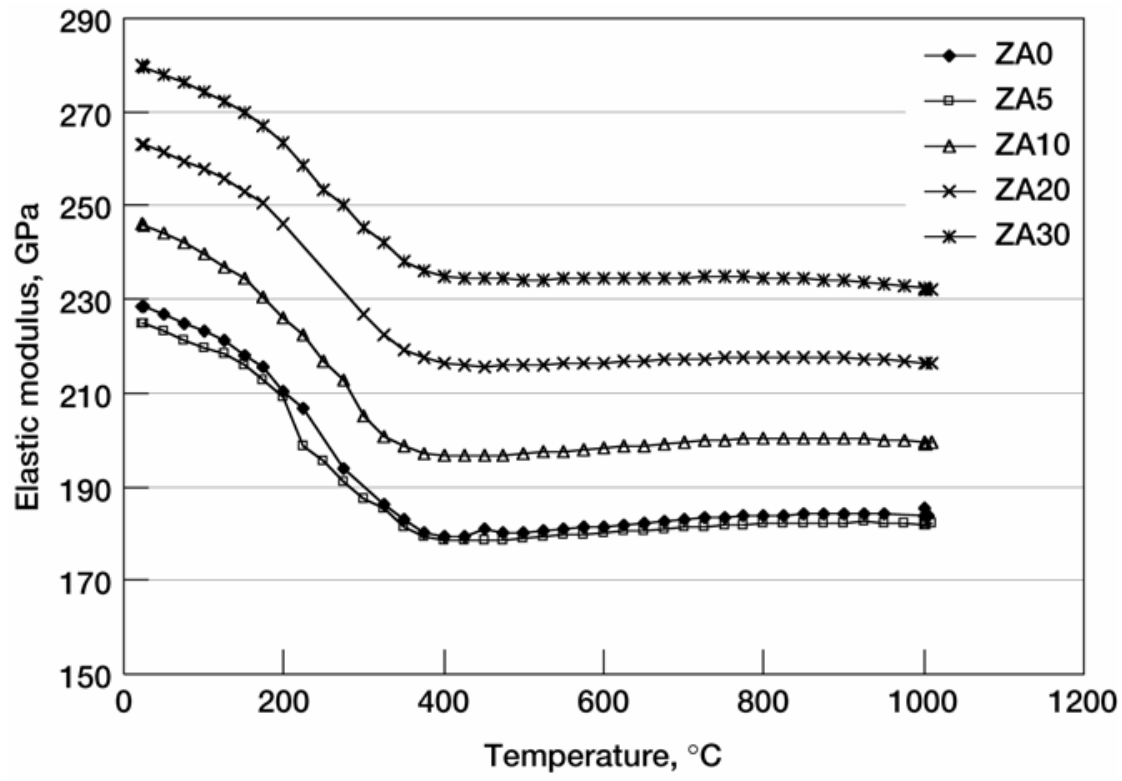

Figure 14. Elastic modulus as a function of temperature for 10-YSZ/alumina particulate composites with different alumina contents, determined by the impulse excitation method.

ZA0 to ZA30 in the figure indicate respective alumina mol\% (e.g., ZA0 $=0 \mathrm{~mol} \%$ ).

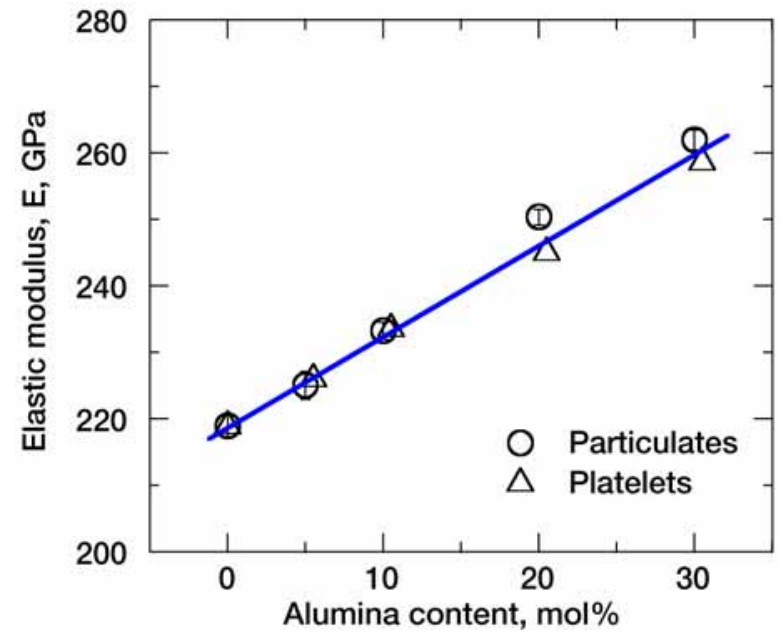

Figure 15. Elastic modulus as a function of alumina content for both 10-YSZ/alumina particulate and platelet composites, determined by the impulse excitation method at ambient temperature [3,4]. Error bars indicate \pm 1.0 standard. The line indicates the prediction based on the rule of mixture.

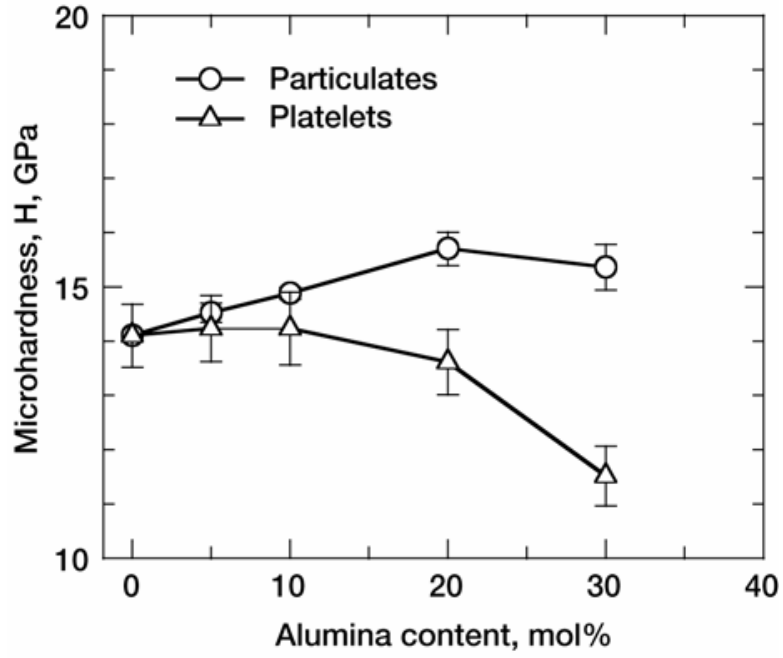

Figure 16. Vickers microhardness as a function of alumina contents for both 10-YSZ/alumina particulate and platelet composites. Error bars indicate \pm 1.0 standard deviations. 


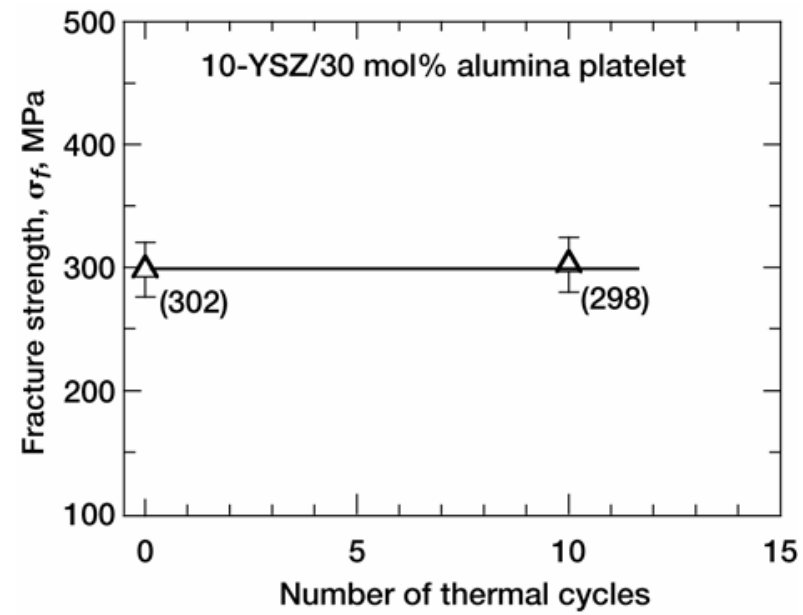

Figure 17. Flexure strength as a function of number of thermal cycles (between 200 and $1000{ }^{\circ} \mathrm{C}$ ) for $10-Y S Z / 30 \mathrm{~mol} \%$ alumina platelet composite [4]. The numbers in parentheses indicate average strength.

\subsection{Microhardness}

Microhardness of both particulate and platelet composites was evaluated at ambient temperature with a Vickers microhardness indenter with an indent load of $9.8 \mathrm{~N}$ using five indents for each composite in accordance with ASTM C 1327 [28]. Figure 16 shows the results of Vickers microhardness measurements for both composites. Microhardness increased linearly with increasing alumina content for the particulate composites up to $20 \mathrm{~mol} \%$ alumina and then leveled up above $20 \mathrm{~mol} \%$. Microhardness of the platelet composites remained almost unchanged up to $10 \mathrm{~mol} \%$ and then decreased appreciably at $30 \mathrm{~mol} \%$, resulting in a significant difference in hardness at $30 \mathrm{~mol} \%$ between the two composites. Individual microhardness data for both composites are also summarized in Tables 1 and 2.

\subsection{Thermal Fatigue}

Thermal cycling/fatigue testing was conducted for the $30 \mathrm{~mol} \%$ platelet composite by applying a total of 10 thermal cycles of heating $\left(1000^{\circ} \mathrm{C}\right)$ and cooling $\left(200^{\circ} \mathrm{C}\right)$ in air using 5 flexure specimens [4]. The rate of heating and cooling was about $10^{\circ} \mathrm{C} / \mathrm{min}$ and $20^{\circ} \mathrm{C} / \mathrm{min}$, respectively. These flexure specimens were then fractured in four-point flexure at ambient temperature to determine their corresponding residual flexure strength. This testing was conducted to better understand the effect of CTE mismatches on flexure strength, possibly resulting in strength degradation due to thermal fatigue associated with residual stresses and/or microcracks induced by CTE mismatches between 10-YSZ matrix and alumina grains.

The result of thermal cycling/fatigue tests is shown in Figure 17. As can be seen in the figure, there was no difference in strength between 0 (regular strength test) and 10 thermal cycles, indicating that repeated thermal cycling up to 10 times did not show any significant effect on strength degradation for the composite material. In other words, internal residual stresses and/or microcracks due to CTE mismatches between zirconia matrix and alumina grains possibly occurring in thermal fatigue were negligible to affect residual flexure strength of the composite material of interest. Hence, it is concluded that CTE mismatches would not have been operative sufficient enough to degrade strength of the composite systems. 


\section{Thermal Conductivity}

One-in.-diameter hot-pressed discs of the particulate composites were used for thermal conductivity measurements. Thermal conductivity testing was carried out using a 3.0-kW $\mathrm{CO}_{2}$ laser (wavelength $10.6 \mu \mathrm{m}$ ) high-heat flux rig. The general test approach has been described elsewhere [29]. In this steadystate laser heat flux test method, the specimen surface was heated by a laser beam, and backside aircooling was used to maintain the desired temperature. A uniform laser heat flux was obtained over the 23.9-mm-diameter aperture region of the specimen surface by using an integrating ZnSe lens combined with the specimen rotation. Platinum wire flat coils (wire diameter of $0.38 \mathrm{~mm}$ ) were used to form thin air gaps between the top aluminum aperture plate and stainless-steel back plate to minimize the specimen heat losses through the fixture.

Figure 18 shows results of thermal conductivities determined from the particulate composites, as a function of temperature [30]. Thermal conductivity increased with increasing alumina content. This is expected, as the thermal conductivity of alumina measured at $1000{ }^{\circ} \mathrm{C}$ is much higher $(6.9 \mathrm{~W} / \mathrm{m}-\mathrm{K})$ [30] than that of $10-\mathrm{YSZ}(2 \mathrm{~W} / \mathrm{m}-\mathrm{K})$. Increase in thermal conductivity with alumina additions is more significant at lower temperatures than at higher temperatures. Thermal conductivity of the composites containing 0,5 , and $10 \mathrm{~mol} \%$ alumina exhibited a slight change with temperature. However, those containing 20 and 30 mol\% alumina showed a sharper decrease in thermal conductivity with increasing temperature. Typical values of thermal conductivity as a function of alumina content determined at $1000^{\circ} \mathrm{C}$ are shown in Table 1.

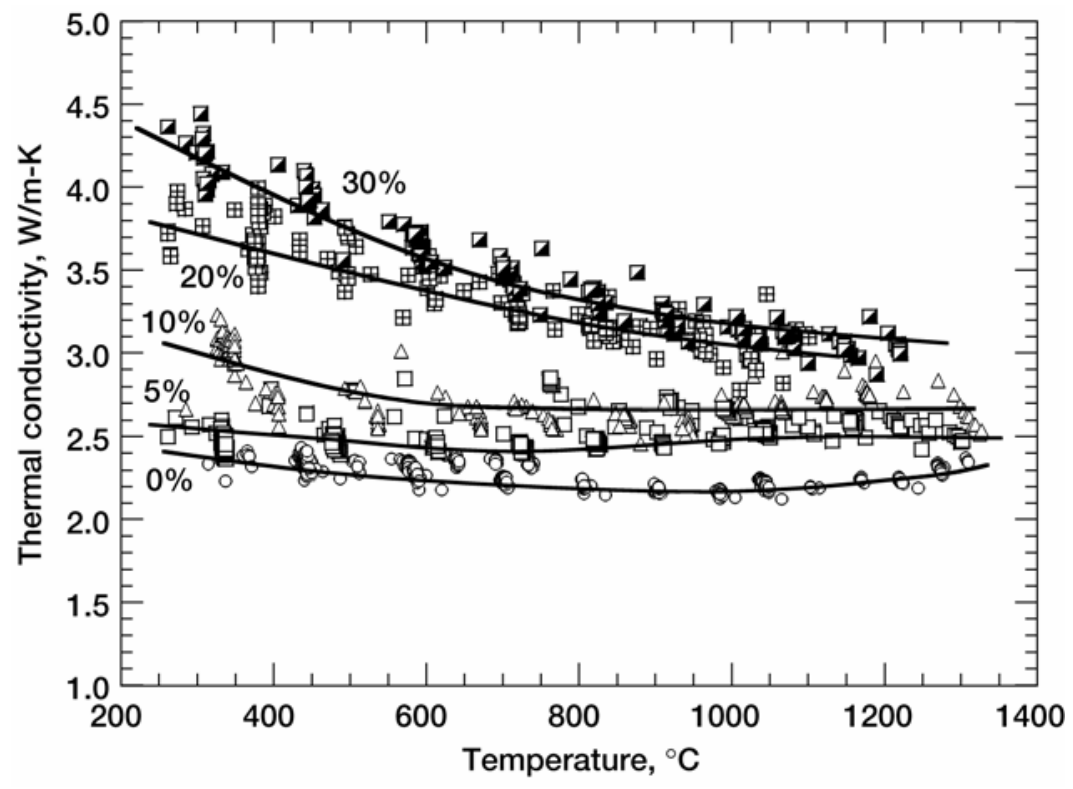

Figure 18. Thermal conductivity as a function of temperature for 10-YSZ/alumina particulate composites containing 0 (10-YSZ), 5, 10, 20 and 30 mol\% alumina, determined by a steady-state laser heat flux technique [30]. 


\section{Choice of Material in View of Structural Reliability/Life}

As seen from the aforementioned properties, the maximum flexure strength at $1000{ }^{\circ} \mathrm{C}$ was achieved with the $30 \mathrm{~mol} \%$ particulate composite, while the maximum fracture toughness at $1000{ }^{\circ} \mathrm{C}$ was attained with the $30 \mathrm{~mol} \%$ platelet composite. The resistance to SCG susceptibility was greater in the $30 \mathrm{~mol} \%$ platelet composite with a higher SCG parameter of $n=33$ than in the $30 \mathrm{~mol} \%$ particulate composites with a lower SCG parameter of $n=6$.

From the structural reliability/life point of view, a composite which gives long life and is strongest (in strength), toughest (in fracture toughness), stiffest (in elastic modulus) and lightest (in weight) is certainly of the best choice for a fuel cell component material. Elastic modulus was found increased with increasing alumina and density, by contrast, decreased with increasing alumina content. It can be shown from Figures 4, 5, 9, and 15 that the $30 \mathrm{~mol} \%$ particulate composite is the best choice of material based on strength, fracture toughness, elastic modulus, and density that were evaluated at ambient temperature. Since operating temperatures of typical SOFCs are within or close to $1000{ }^{\circ} \mathrm{C}$, a choice of a candidate material should not be solely based on ambient temperature properties but based on elevated temperature properties, particularly slow crack growth, which controls life of fuel cell components.

With respect to elevated-temperature strength, the $30 \mathrm{~mol} \%$ particulate composite is better than the platelet counterpart. By contrast, with regard to fracture toughness and SCG resistance, the platelet composite is better than the particulate counterpart. Hence, a unified choice of $a$ material to satisfy all of the important requirements—strong, tough, long life—can hardly be made. A case-by-case selection, depending on the types of operation/service conditions (temperature, loading (continuous or intermittent), environment, and components configurations, etc.), is needed. For example, if the components are subjected to a continuous, isothermal type of operations without frequent interruption (thus encountering little thermal shock loading, etc.), then the $30 \mathrm{~mol} \%$ platelet composite would be a good candidate since the material would give longer service life of components. This structural consideration should not neglect the SOFC's important electrical performance, that is, oxygen $\left(\mathrm{O}^{2-}\right)$-ion conductivity. Preliminary results, however, have shown that electrical conductivities of both particulate and platelet composites, determined between 500 to $1100{ }^{\circ} \mathrm{C}$, were insignificant with respect to alumina content [4].

\section{Summary}

At ambient temperature, both flexure strength and fracture toughness increased with increasing alumina content, reaching a maximum at $30 \mathrm{~mol} \%$. For a given alumina content, strength of particulate composites was greater than that of platelet composites. Fracture toughness increased with alumina content with little difference in fracture toughness between the two composites.

At $1000{ }^{\circ} \mathrm{C}$, the $30 \mathrm{~mol} \%$ particulate composites yielded the maximum strength, whereas the 30 mol\% platelet composite exhibited the maximum fracture toughness. Fracture toughness was approximately 16 percent greater in the platelet composites than in the particulate composites.

The susceptibility to slow crack growth was high for both 0 and $30 \mathrm{~mol} \%$ particulate composites with lower SCG parameters of $n=6-8$, whereas the susceptibility to SCG was low for the $30 \mathrm{~mol} \%$ platelet composite with its higher SCG parameter of $n=33$.

No significant difference in elastic modulus and density was observed for a given alumina content between the particulate and platelet composites. In both cases, the prediction by the rule of mixture was in good agreement with the experimental data. Elevated-temperature elastic modulus of both composite systems was characterized with a well-defined transition around $400{ }^{\circ} \mathrm{C}$, below which elastic modulus decreased monotonically and above which it remained almost unchanged up to $1000{ }^{\circ} \mathrm{C}$. Vickers microhardness of the particulate composites increased with increasing alumina content; while Vickers microhardness of the platelet composites followed an opposite trend, in which a significant decrease in hardness resulted in higher alumina contents. Thermal conductivity increased with increasing alumina 
content. Thermal conductivity showed slight change with temperature for 0,5 , and $10 \mathrm{~mol} \%$ alumina compositions, whereas it decreased with temperature for composites containing 20 and $30 \mathrm{~mol} \%$ alumina.

Thermal cycling/fatigue up to 10 cycles between 200 to $1000{ }^{\circ} \mathrm{C}$ did not show any adverse effect on strength degradation of the $30 \mathrm{~mol} \%$ platelet composites, indicative of negligible influence of CTE mismatches on residual stresses and/or microcracking between YSZ matrix and alumina grains.

\section{References}

1. N. Q. Minh, Ceramic fuel cells, J. Am. Ceram. Soc., 76[3] 563-588 (1993).

2. S. R. Choi and N. P. Bansal, Strength and fracture toughness of zirconia/alumina composites for solid oxide fuel cells," Ceram. Eng. Sci. Proc., 23[3] 741-750 (2002).

3. N. P. Bansal and S. R. Choi, Processing of alumina-toughened zirconia composites, NASA/TM2003-212451, National Aeronautics and Space Administration, Glenn Research Center, Cleveland, OH (2003).

4. S. R. Choi and N. P. Bansal, Processing and mechanical properties of various zirconia/alumina composites for fuel cells applications, NASA/TM-2002-211580, National Aeronautics and Space Administration, Glenn Research Center, Cleveland, OH (2002); also CIMTEC 2002 Conference, paper no. G1:P03, June 14-18, 2002, Florence, Italy.

5. S. R. Choi and N. P. Bansal, Strength, fracture toughness, and slow crack growth of zirconia/alumina composites at elevated temperature, NASA/TM-2003-212108, National Aeronautics and Space Administration, Glenn Research Center, Cleveland, OH (2002).

6. S. R. Choi and N. P. Bansal, High-temperature flexure strength, fracture toughness, and fatigue of zirconia/alumina composites, to be published in Ceram. Eng. Sci. Proc., 24[3] (2003).

7. ASTM C 1161, Test method for flexural strength of advanced ceramics at ambient temperature, Annual Book of ASTM Standards, Vol. 15.01, American Society for Testing \& Materials, West Conshohocken, PA (2001).

8. (a) S. R. Choi and J. P. Gyekenyesi, 'Ultra'-fast fracture strength of advanced structural ceramics at elevated temperatures: an approach to high-temperature 'inert' strength,” pp. 27-46 in Fracture Mechanics of Ceramics, Vol. 13, Edited by R. C. Bradt, D. Munz, M. Sakai, V. Ya. Shevchenko, and K. W. White, Kluwer Academic/Plenum Publishers, New York (2002); (b) S. R. Choi and J. P. Gyekenyesi, Elevated-temperature 'ultra'-fast fracture strength of advanced ceramics: an approach to elevated-temperature 'inert' strength, ASME J. Eng. Gas Turbines \& Powers, 121 18-24 (1999).

9. ASTM C 1211, Test method for flexural strength of advanced ceramics at elevated temperatures, Annual Book of ASTM Standards, Vol. 15.01, American Society for Testing and Materials, West Conshohocken, PA (2001).

10. F. F. Lange, Transformation toughening; Part 4. Fabrication, fracture toughness and strength of $\mathrm{Al}_{2} \mathrm{O}_{3}-\mathrm{ZrO}_{2}$ composites,” J. Mater. Sci., 17 247-254 (1982).

11. I. K. Cherian and W. M. Kriven, Alumina-platelet-reinforced 3Y-TZP, Am. Ceram. Soc. Bull., 80[12] 57-63 (2001).

12. J. Kübler, (a) Fracture toughness of ceramics using the SEVNB method: preliminary results, Ceram. Eng. Sci. Proc., 18[4] 155-162 (1997); (b) Fracture toughness of ceramics using the SEVNB method; round robin, VAMAS Report No. 37, EMPA, Swiss Federal Laboratories for Materials Testing \& Research, Dübendorf, Switzerland (1999).

13. ASTM C 1421, Test methods for determination of fracture toughness of advanced ceramics at ambient temperature, Annual Book of ASTM Standards, Vol. 15.01, American Society for Testing and Materials, West Conshohocken, PA (2001). 
14. (a) S. R. Choi and V. Tikare, Crack healing of alumina with a residual glassy phase: strength, fracture toughness and fatigue, Matl. Sci. Eng. A171 77-83 (1993); (b) S. R. Choi and V. Tikare, Crack healing in silicon nitride due to oxidation, Ceram. Eng. Sci. Proc., 12[9-10] 2190-2202 (1991).

15. J. E. Srawley and B. Gross, Side-cracked plates subjected to combined direct and bending forces, pp. 559-579 in Cracks and Fracture, ASTM STP 601, American Society for Testing and Materials, Philadelphia (1976).

16. ASTM C 1465, Test method for determination of slow crack growth parameters of advanced ceramics by constant stress-rate flexural testing at elevated temperatures, Annual Book of ASTM Standards, Vol. 15.01, American Society for Testing and Materials, West Conshohocken, PA (2001).

17. S. M. Wiederhorn, Subcritical crack growth in ceramics, pp. 613-646 in Fracture Mechanics of Ceramics, Vol. 2, Edited by R. C. Bradt, D. P. H. Hasselman, and F. F. Lange, Plenum Press, New York (1974).

18. F. F. Lange, High-temperature strength behavior of hot-pressed $\mathrm{Si}_{3} \mathrm{~N}_{4}$ : evidence of subcritical crack growth, J. Am. Ceram. Soc., 57 84-87 (1974).

19. J. E. Weston and P. L. Pratt, Crystallization of grain boundary phases in hot-pressed silicon nitride materials, J. Mater. Sci., 13 2147-2156 (1978).

20. R. L. Tsai and R. Raj, The role of grain boundary sliding in fracture of hot-pressed $\mathrm{Si}_{3} \mathrm{~N}_{4}$ at high temperatures, J. Am. Ceram. Soc., 63 [1-2] 513-517 (1980).

21. K. Jakus, T. Service, and J. E. Ritter, High-temperature fatigue behavior of polycrystalline alumina, J. Am. Ceram. Soc., 64 4-7 (1980).

22. A. G. Evans, Slow crack growth in brittle materials under dynamic loading condition, Int. J. Fracture, 10 [2] 251-259 (1974).

23. ASTM C 1368, Test method for determination of slow crack growth parameters of advanced ceramics by constant stress-rate flexural testing at ambient temperature, Annual Book of ASTM Standards, Vol. 15.01, American Society for Testing and Materials, West Conshohocken, PA (2001).

24. S. R. Choi and J. P. Gyekenyesi, Specimen geometry effect on the determination of slow crack growth parameters of advanced ceramics in constant flexural stress-rate testing at elevated temperatures, Ceram. Eng. Sci. Proc., 20[3] 525-534 (1999).

25. N. N. Nemeth, L. M. Powers, L. A. Janosik, and J. P. Gyekenyesi, Time dependent reliability analysis of monolithic ceramic components using the CARES/LIFE integrated design program, pp. 390-408 in Life Prediction Methodologies and Data for Ceramic Materials, ASTM STP 1201, Edited by C. R. Brinkman and S. F. Duffy, American Society for Testing and Materials, Philadelphia (1994).

26. ASTM C 1259, Test method for dynamic Young's modulus, shear modulus, and Poisson's ratio for advanced ceramics by impulse excitation of vibration, Annual Book of ASTM Standards, Vol. 15.01, American Society for Testing and Materials, West Conshohocken, PA (2001).

27. J. W. Adams, R. Ruh, and K. S. Mazdiyasni, Young's modulus, flexural strength, and fracture of yttria-stabilized zirconia versus temperature, J. Am. Ceram. Soc., 80[4] 903-908 (1997).

28. ASTM C 1327, Test method for Vickers indentation hardness of advanced ceramics, Annual Book of ASTM Standards, Vol. 15.01, American Society for Testing and Materials, West Conshohocken, PA (2001).

29. D. Zhu, N. P. Bansal, K. N. Lee, and R. A. Miller, Thermal conductivity of ceramic thermal barrier and environmental barrier coating materials, NASA/TM-2001-211122, National Aeronautics and Space Administration, Glenn Research Center, Cleveland, OH (2001).

30. N. P. Bansal and D. Zhu, Thermal conductivity of alumina-toughened zirconia composites, to be published in NASA TM, National Aeronautics and Space Administration, Glenn Research Center, Cleveland, $\mathrm{OH}$ (2003). 


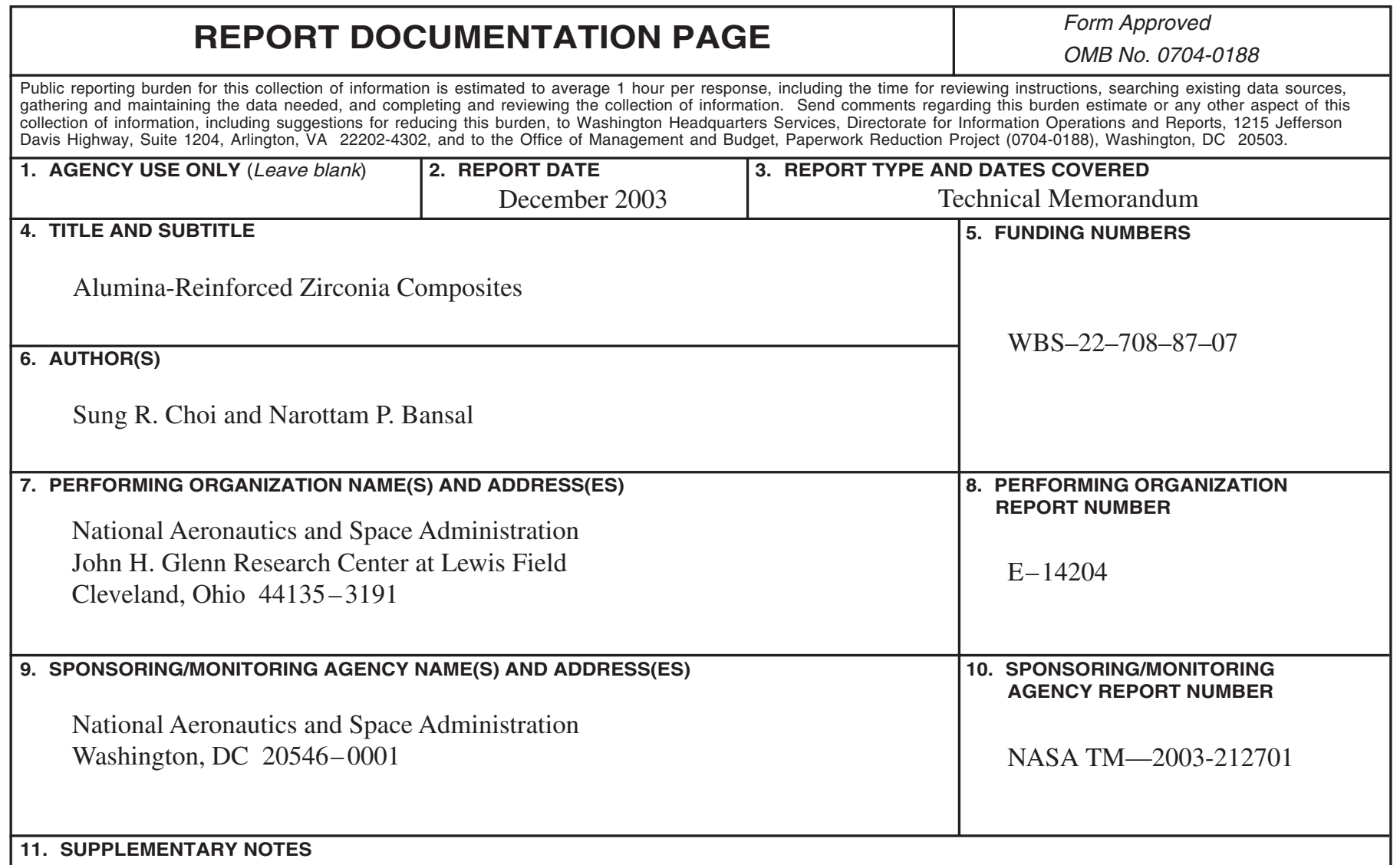

Sung R. Choi, Ohio Aerospace Institute, Brook Park, Ohio 44142; and Narottam P. Bansal, NASA Glenn Research Center. Responsible person, Sung R. Choi, organization code 5920, 216-433-8366.

12a. DISTRIBUTION/AVAILABILITY STATEMENT 12b. DISTRIBUTION CODE

Unclassified - Unlimited

Subject Categories: 07 and 39

Distribution: Nonstandard

Available electronically at http://gltrs.grc.nasa.gov

This publication is available from the NASA Center for AeroSpace Information, 301-621-0390.

13. ABSTRACT (Maximum 200 words)

Alumina-reinforced zirconia composites, used as electrolyte materials for solid oxide fuel cells, were fabricated by hot pressing $10 \mathrm{~mol} \%$ yttria-stabilized zirconia (10-YSZ) reinforced with two different forms of alumina-particulates and platelets - each containing 0 to $30 \mathrm{~mol} \%$ alumina. Major mechanical and physical properties of both particulate and platelet composites including flexure strength, fracture toughness, slow crack growth, elastic modulus, density, Vickers microhardness, thermal conductivity, and microstructures were determined as a function of alumina content either at $25^{\circ} \mathrm{C}$ or at both 25 and $1000{ }^{\circ} \mathrm{C}$. Flexure strength and fracture toughness at $1000{ }^{\circ} \mathrm{C}$ were maximized with 30 mol\% particulate and $30 \mathrm{~mol} \%$ platelet composites, respectively, while resistance to slow crack growth at $1000{ }^{\circ} \mathrm{C}$ in air was greater for $30 \mathrm{~mol} \%$ platelet composite than for $30 \mathrm{~mol} \%$ particulate composites.

\begin{tabular}{|c|c|c|}
\hline \multicolumn{3}{|c|}{$\begin{array}{l}\text { Ceramic composites; Zirconia-alumina composites; Mechanical properties; Strength; } \\
\text { Fracture toughness; Slow crack growth; Elastic modulus; Thermal conductivity }\end{array}$} \\
\hline $\begin{array}{l}\text { 17. SECURITY CLASSIFICATION } \\
\text { OF REPORT }\end{array}$ & $\begin{array}{l}\text { 18. SECURITY CLASSIFICATION } \\
\text { OF THIS PAGE }\end{array}$ & $\begin{array}{l}\text { 19. SECURITY CLASSIFICATION } \\
\text { OF ABSTRACT }\end{array}$ \\
\hline Unclassified & Unclassified & Unclassified \\
\hline
\end{tabular}

NSN 7540-01-280-5500

15. NUMBER OF PAGES

16. PRICE CODE

20. LIMITATION OF ABSTRACT

Standard Form 298 (Rev. 2-89)

Prescribed by ANSI Std. Z39-18 298-102 